\title{
Quantum Dots Enhanced Ultrasensitive Detection of DNA Adducts
}

\author{
Zhixin Wang, ${ }^{\dagger}$ Meiling Lu, ${ }^{\dagger}$ Xiaoli Wang, ${ }^{\dagger}$ Ruichuan Yin, ${ }^{\dagger}$ Yuling Song, ${ }^{\dagger} X$. Chris Le, ${ }^{\ddagger}$ and \\ Hailin Wang*,t
}

\author{
State Key Laboratory of Environmental Chemistry and Ecotoxicology, Research Center for Eco-Environmental \\ Sciences, Chinese Academy of Sciences, 100085, China, and Department of Laboratory Medicine and Pathology, \\ University of Alberta, Edmonton, T6G 2G3, AB, Canada
}

Here we demonstrate that quantum dots (QD) can greatly improve the ultrasensitive capillary electrophoresis-laser induced fluorescence immunoassay of trace anti-benzo(a)pyrene diol epoxide (BPDE)-DNA adducts from sensitivity to separation. We for the first time show that the target $\mathrm{QD}$-antibody-DNA complex is not only effectively separated but also effectively focused by capillary electrophoresis. With the online laser-induced fluorescence detection coupled, the low limits of detection of 6.6 $\times 10^{-21} \mathrm{~mol}$ in mass and $120 \mathrm{fM}$ in concentration are achieved for BPDE-DNA adducts. The achieved ultrasensitivity allows for human exposure biomonitoring and shows promising applications of QD in various DNA analyses, including DNA damage.

Ultrasensitive analysis is a combat of detecting weak signal against the noises resulting from nonspecific adsorption, fluorescence impurities, and Raman scattering. It is hard for the traditional organic dyes to overcome these restrictions. Because of the exceptional optical properties and well-controlled nanosurface, semiconductor quantum dots (QD) hold much promise for ultrasensitive analysis. ${ }^{1-4}$ However, it also raises a great challenge because of the difficulty to separate the QD bound biomolecules of interest from the unbound $\mathrm{QD}$, resulting from their similarly large size and high density. ${ }^{5}$ The success in separation is essential for achieving desirable ultrasensitivity and specificity. By taking advantage of the potentials of QD and combining the advantages of highly efficient separation and ultrasensitivity of capillary electrophoresis coupled laser-induced fluorescence (CE-LIF), we demonstrate the quantification of representative DNA adducts, anti-benzo (a) pyrene diol epoxide (BPDE) -DNA adducts, with a low detection limit of several zeptomoles in mass and femtomoles

* To whom correspondence should be addressed. Phone/fax: +86-1062849600. E-mail: hlwang@rcees.ac.cn.

${ }^{\dagger}$ Chinese Academy of Sciences.

${ }^{*}$ University of Alberta.

(1) Gill, R.; Zayats, M.; Willner, I. Angew. Chem., Int. Ed. 2008, 47, 76027625.

(2) Resch-Genger, U.; Grabolle, M.; Cavaliere-Jaricot, S.; Nitschke, R.; Nann, T. Nat. Methods 2008, 5, 763-775.

(3) Michalet, X.; Pinaud, F. F.; Bentolila, L. A.; Tsay, J. M.; Doose, S.; Li, J. J.; Sundaresan, G.; Wu, A. M.; Gambhir, S. S.; Weiss, S. Science 2005, 307, 538-544.

(4) Howarth, M.; Liu, W.; Puthenveetil, S.; Zheng, Y.; Marshall, L. F.; Schmidt, M. M.; Wittrup, K. D.; Bawendi, M. G.; Ting, A. Y. Nat. Methods 2008, 5, 397-399.

(5) Vicente, G.; Colon, L. A. Anal. Chem. 2008, 80, 1988-1994. in concentration using nanograms of DNA. The formation of carcinogenic BPDE-DNA adducts in organisms mainly results from the exposure to a ubiquitous environmental pollutant benzo $(a)$ pyrene $(\mathrm{B}(\mathrm{a}) \mathrm{P}){ }^{6-8}$ When armed with an ultrasensitive method for detection of trace DNA adducts resulting from low levels of exposure relevant to environmental settings, DNA adducts as carcinogen biomarkers can provide essential and quantitative information for a realistic and meaningful assessment of environmental exposure and cancer risk and prevention..$^{9-11}$

\section{EXPERIMENTAL SECTION}

Caution. B(a)P and anti-BPDE are carcinogenic and should be handled with extreme caution.

Chemicals and Reagents. Benzo (a)pyrene $(\mathrm{B}(\mathrm{a}) \mathrm{P})$ and antibenzo (a)pyrene-trans-7,8-dihydrodiol-9,10-epoxide (anti-BPDE) were supplied by the National Cancer Institute Chemical Carcinogen Reference Standard Repository (Kansas, MO). Mouse monoclonal anti-BPDE-dG antibody (mAb 8E11) was from Trevigen (Gaithersburg, $\mathrm{MD}$ ). Qdot 625 goat $\left.\mathrm{F}(\mathrm{ab})_{2}\right)_{2}$ antimouse IgG conjugate $(\mathrm{H}+\mathrm{L})$ and bovine serum albumin (BSA) were from Invitrogen (Carlsbad, $\mathrm{CA}$ ). Deionized water was obtained from a Purelab Ultra Bioscience water purification system (ELGA, U.K.). Uncoated fused-silica square capillary (50 $\mu \mathrm{m}$ square i.d., $373 \mu \mathrm{m}$ o.d.) was purchased from Polymicro Technologies (Phoenix, AZ). All other reagents and solvents were of analytical or HPLC grade.

Cell Culture and Treatment. To simulate the generation of BPDE-DNA adducts at environmental settings, human lung carcinoma A549 cells were incubated with anti-BPDE, B (a)P, and cigarette-smoke condensate as low as $0.1 \mathrm{nM}, 1 \mathrm{nM}$, and from less than one cigarette, respectively. The A549 cells were grown in $6 \mathrm{~cm}$ plates and maintained in $4.0 \mathrm{~mL} / \mathrm{plate}$ RPMI 1640 medium (Hyclone, South Logan, Australian) supplemented with 10\% fetal bovine serum (Gibco BRL, Gaithersburg, MD), $100 \mathrm{U} / \mathrm{mL}$ penicillin $\mathrm{G}$ (Hyclone), and $100 \mathrm{U} / \mathrm{mL}$ streptomycin sulfate

(6) Phillips, D. H. Nature 1983, 303, 468-472.

(7) Denissenko, M. F.; Pao, A.; Tang, M.-s.; Pfeifer, G. P. Science 1996, 274, 430-432.

(8) Feng, Z.; Hu, W.; Hu, Y.; Tang, M.-s. Proc. Natl. Acad. Sci. U.S.A. 2006 , 17, 15404-15409.

(9) Hecht, S. S. Nat. Rev. Cancer 2003, 3, 733-744.

(10) Swenberg, J. A.; Fryar-Tita, E.; Jeong, Y.-C.; Boysen, G.; Starr, T.; Walker, V. E.; Albertini, R. J. Chem. Res. Toxicol. 2008, 21, 253-265.

(11) Li, D.; Wang, L.; Chang, P.; El-Nagggar, A. K.; Sturgis, E. M.; Wei, Q. Cancer Res. 2007, 67, 5628-5634. 
(Hyclone) at $95 \%$ humidity and $5 \% \mathrm{CO}_{2}$ for $2-3$ days prior to use. The cultured A549 cells (about $5 \times 10^{6}$ cells per plate) were treated for $2 \mathrm{~h}$ with racemic anti-BPDE of different doses $(0-10 \mathrm{nM})$. The anti-BPDE was freshly dissolved in tetrahydrofuran/triethylamine solution (THF/TEA, 19:1, v/v) and 2.0 $\mu \mathrm{L}$ solution was added to each plate. For the control, only 2.0 $\mu \mathrm{L}$ of THF/TEA solution was added into each plate. For the $\mathrm{B}(\mathrm{a}) \mathrm{P}$ exposure, the cells were incubated for $16 \mathrm{~h}$ with $\mathrm{B}(\mathrm{a}) \mathrm{P}$, dissolved in dimethylsulfoxide (DMSO) of different doses $(0-50 \mathrm{nM})$. The control cells were treated only by DMSO (2.0 $\mu \mathrm{L} / 4 \mathrm{~mL}$ medium). After treatments, the cells were subsequently washed with phosphate buffered saline prior to DNA extraction. The genomic DNA was extracted from the cultured A549 cells using Wizard genomic DNA purification kits (Promega, Madison, WI), according to the protocol of the manufacturer. The DNA concentration was estimated at UV $260 \mathrm{~nm}$.

The commercial cigarettes used in the experiment were purchased from a local retail store. The smoke generated from one and five cigarettes were bubbled through $500 \mu \mathrm{L}$ of ethanol at room temperature by using a designed smoke-aspirating apparatus (Supporting Information, Figure S1A) to extract B(a)P. ${ }^{12}$ One tenth of the extract solution $(50 \mu \mathrm{L})$ was added into one plate with confluent A549 cells for each dose. In the control dish, 50 $\mu \mathrm{L}$ of ethanol was added. The cell treatment was duplicated for each dose. After incubation for $16 \mathrm{~h}$, the genomic DNA was extracted as described above.

CE-LIF Immunoassay of anti-BPDE-DNA Adducts. CELIF analysis was performed on a laboratory-built CE-LIF system as described previously. ${ }^{13}$ A $488 \mathrm{~nm}$ solid-state laser $(30 \mathrm{~mW}$, Melles Griot, Irvine, CA) was used for excitation, and the emitted fluorescence was detected at $625 \mathrm{~nm}$. Genomic DNA extracted from cell cultures was denatured by heating at $95{ }^{\circ} \mathrm{C}$ for $5 \mathrm{~min}$ followed by chilling in ice. The denatured DNA was mixed with $1.5 \mathrm{nM}(0.25 \mu \mathrm{g} / \mathrm{mL})$ primary antibody mAb 8E11, $5 \mathrm{nM}$ secondary antibody $\mathrm{QD}-2^{\circ} \mathrm{Ab}$, and $100 \mu \mathrm{g} / \mathrm{mL}$ BSA in a Trisacetate buffer (TA, $20 \mathrm{mM}$ Tris and $4 \mathrm{mM}$ acetic acid, $\mathrm{pH}=7.8$ ). Addition of nonspecific proteins, such as BSA, can enhance the formation and stability of the ternary complex between the antibodies and the DNA adduct and improve the reproducibility of the analysis. ${ }^{14}$ The samples were incubated at room temperature for at least $30 \mathrm{~min}$ prior to CE-LIF analysis. Uncoated fused-silica square capillaries of $50 \mu \mathrm{m}$ square i.d. were covalently coated with a monolayer of linear polyacrylamide (PAA) as described previously. ${ }^{13}$ The capillary was $26 \mathrm{~cm}$ long with an effective length of $20 \mathrm{~cm}$ from the inlet to the detection window. A negative voltage of $20 \mathrm{kV}$ was applied to the injection end of the capillary, and the outlet end (near detection window) was grounded. Samples were electrokinetically injected into the capillary by applying an injection voltage of $-20 \mathrm{kV}$ for $10 \mathrm{~s}$. All the separations were carried out at room temperature. The separation buffer was $1 \times$ Tris-glycine buffer (TG, $30 \mathrm{mM}$ Tris and $160 \mathrm{mM}$ glycine, $\mathrm{pH}=8.5$ ). All buffers were filtered through a $0.22 \mu \mathrm{m}$ membrane filter and degassed using ultrasonication before use. After each analysis, the capillary

(12) Singh, R.; Kaur, B.; Farmer, P. B. Chem. Res. Toxicol. 2005, 18, 249-256.

(13) Wang, Z.; Wang, C.; Yin, J.; Li, T.; Song, M.; Lu, M.; Wang, H. Electrophoresis 2008, 29, 4454-4462.

(14) Wang, H.; Lu, M.; Weinfeld, M.; Le, X. C. Anal. Chem. 2003, 75, 247-254. was washed by $50 \%(\mathrm{v} / \mathrm{v})$ methanol/water solution and running buffer for $5 \mathrm{~min}$ in sequence.

\section{RESULTS AND DISCUSSION}

The immunoassay of the BPDE-DNA adducts is illustrated in Figure 1a. Mouse monoclonal antibody $(\mathrm{mAb}) 8 \mathrm{E} 11$ was chosen for specific recognition of single anti-BPDE $-N^{2}-\mathrm{dG}$ adducts in genomic DNA because of its no observable cross-reaction against normal DNA and high affinity $\left(K_{\mathrm{a}}=2.5 \times 10^{8} \mathrm{M}^{-1}\right){ }^{15}$ $\mathrm{QD} 625$ goat $\mathrm{F}\left(\mathrm{ab}^{\prime}\right)_{2}$ antimouse IgG conjugate (QD-2 $\left.{ }^{\circ} \mathrm{Ab}\right)$ was chosen for selectively labeling $\mathrm{mAb} 8 \mathrm{E} 11$ and its immunocomplex of DNA adducts. The QD- $2^{\circ} \mathrm{Ab}$ was excited at $488 \mathrm{~nm}$ and detected at the maximum emission of $625 \mathrm{~nm}$. By the excitation at $488 \mathrm{~nm}$ and the emission at $625 \mathrm{~nm}$, the strong Raman scattering from water (distributed at $490-530 \mathrm{~nm}$ and $572-588 \mathrm{~nm}$ ) can be bypassed (Supporting Information, Figure S2). In addition, agarose gel electrophoresis analysis shows that the $\mathrm{QD}-2^{\circ} \mathrm{Ab}$ migrated toward the anode (Supporting Information, Figure S3), suggesting that the $\mathrm{QD}-2^{\circ} \mathrm{Ab}$ has been sparsely modified by negative charge. This property will greatly reduce both the nonspecific adsorption of DNA on the nanosurface and the interaction of the $\mathrm{QD}-2^{\circ} \mathrm{Ab}$ with the inner capillary surface. Our agarose gel electrophoresis analysis of the mixture of QD$2^{\circ} \mathrm{Ab}$ and normal DNA confirms the former point (data not shown), and the symmetry CE peak of QD- ${ }^{\circ} \mathrm{Ab}$ (peak 2, Figure 1b) confirms the latter point. In the immuno-reaction solutions, the $\mathrm{QD}-2^{\circ} \mathrm{Ab}, \mathrm{mAb} 8 \mathrm{E} 11$, and BPDE adduct containing DNA can form the complexes of QD-antibody-DNA. However, these large complexes are mixed with $\mathrm{QD}-2^{\circ} \mathrm{Ab}$ and the complex of QD$2^{\circ} \mathrm{Ab}-\mathrm{mAb} 8 \mathrm{E} 11$ (Figure 1a). The normal DNA because of a lack of target adducts will not be labeled by QD- $2^{\circ} \mathrm{Ab}$. Therefore, there is no need to separate the $\mathrm{QD}$-antibody-DNA complexes from the QD unbound genomic DNA ( $>20 \mathrm{~kb})$. However, it requires effective separation of the QD-antibody-DNA complexes from DNA unbound $\mathrm{QD}-2^{\circ} \mathrm{Ab}$. By application of optimized neutral capillary electrophoresis, the large complex of QD-antibody-DNA $(\sim 1.5 \mathrm{~min}, \leq 20 \mathrm{pM})$ can be completely separated from the 250 times more QD-2 $\mathrm{Ab}(2.8 \mathrm{~min}, 5 \mathrm{nM})$ (Figure $1 \mathrm{~b})$. The complexes of QD-antibody-DNA because of the excess negative charge of the bound DNA migrate faster toward the detection window (near the anode end) than the DNA unbound QD species (Figure 1a). Interestingly, even two major complexes of $\mathrm{QD}-$ antibody-DNA (1.50 and $1.53 \mathrm{~min}$ ) are resolvable (Figure 1c). The observation of the two complexes is coincident with the bivalent property of the primary antibody IgG and consistent with previous work, ${ }^{15}$ attributing to the immunocomplexes of different binding stoichiometry. Under the optimized conditions, the complex of QD$2^{\circ} \mathrm{Ab}-\mathrm{mAb} 8 \mathrm{E} 11$ with BPDE adducts in a short 90mer DNA strand ( $\ll 20 \mathrm{~kb}$ genomic DNA) is also resolvable from the unbound $\mathrm{QD}-2^{\circ} \mathrm{Ab}$ (data not shown). All the separations were achieved on free solution $\mathrm{CE}$ and no sieving matrix was involved, demonstrating the separation potential of free solution $\mathrm{CE}$ in $\mathrm{QD}$ enhanced immunoassays. It is interesting that a DNA-driven focusing method described for enhancing protein-DNA binding assays ${ }^{16}$ is also applicable to the focusing of the QD-antibody-

(15) Wang, H.; Xing, J.; Tan, W.; Lam, M.; Carnelley, T.; Weinfeld, M.; Le, X. C. Anal. Chem. 2002, 74, 3714-3719.

(16) Wang, H.; Lu, M.; Le, X. C. Anal. Chem. 2005, 77, 4985-4990. 
(a)
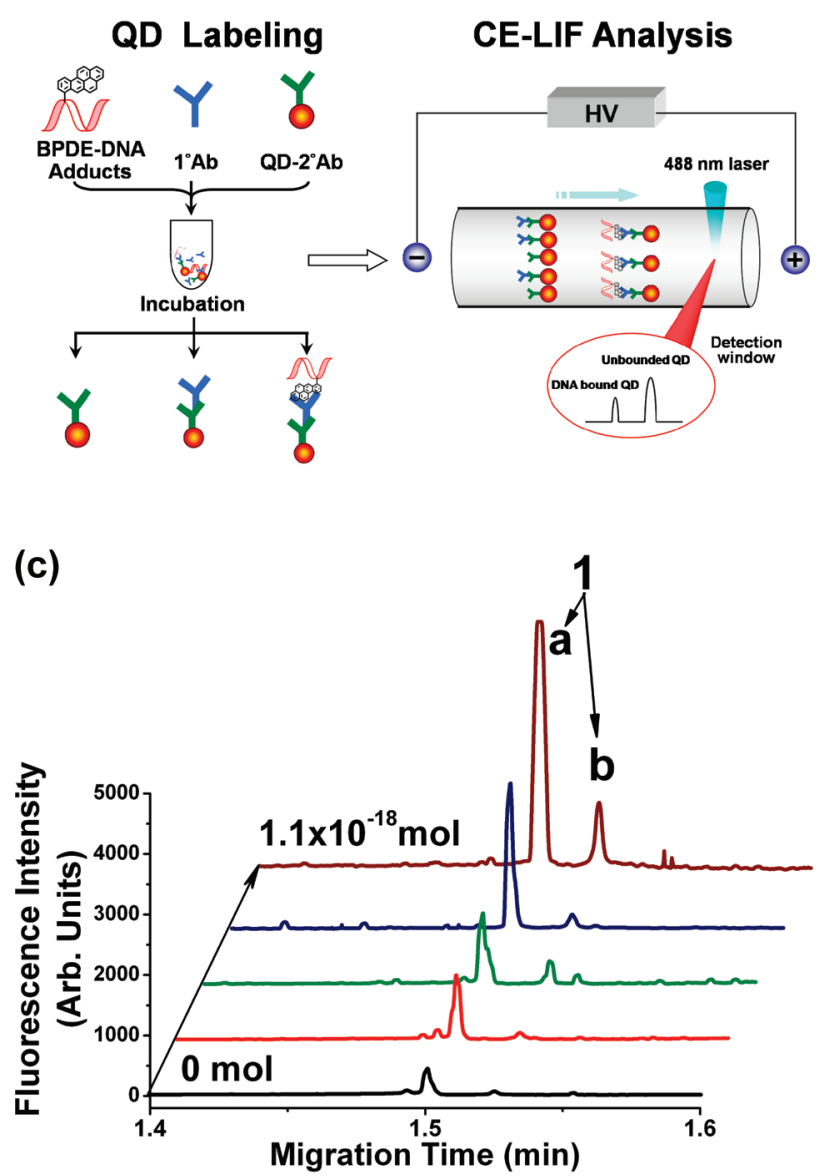

(b)

)

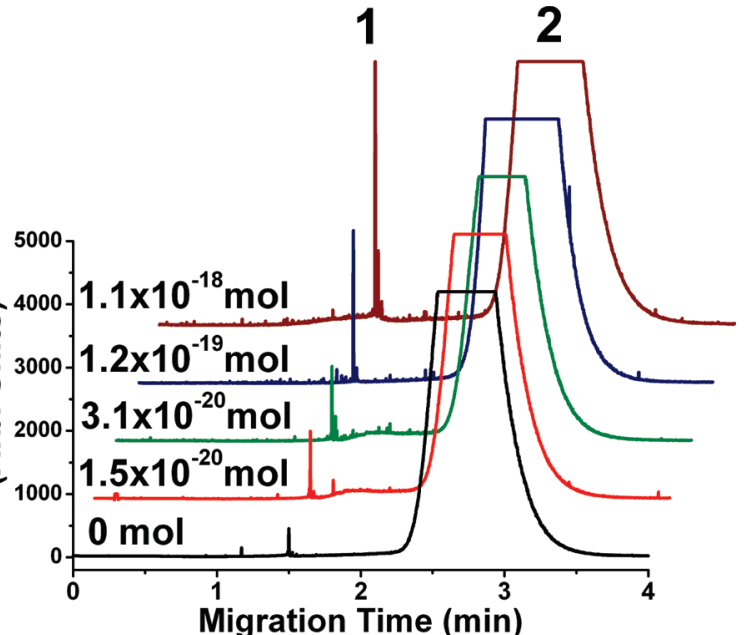

(d)

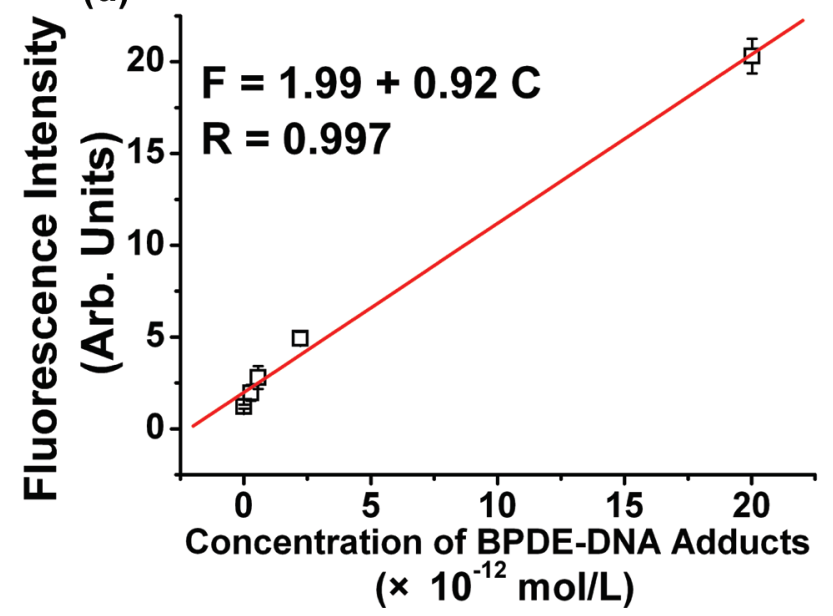

Figure 1. A QD based CE-LIF immunoassay for detection of BPDE-DNA adducts. (a) The BPDE-DNA adducts are first specifically bound to $1^{\circ} \mathrm{Ab}$ (mAb 8E11), then selectively labeled by QD-2 $\mathrm{Ab}$, and followed by CE-LIF analysis. (b) Electropherograms from CE-LIF analysis of QD labeled BPDE-DNA adducts. The standard BPDE-DNA adducts are varied from 0 to $1.1 \times 10^{-18}$ mol. (c) The electropherogram in part $b$ from 1.4-1.6 min. Peaks $1 \mathrm{a}$ and $1 \mathrm{~b}$ correspond to the two complexes of Qdot- ${ }^{\circ} \mathrm{Ab}-\mathrm{mAb}$ 8E11-DNA and peak 2 corresponds to the excess DNA unbound QD. (d) The linear plot of the QD-antibody-DNA complex against the concentration of BPDE-DNA adducts.

DNA complex. As shown in Figure 1b, the large complex of QD-antibody-DNA has a 2000 times higher separation efficiency (over 1.7 million theoretical plates per meter) than $\mathrm{QD}-2^{\circ} \mathrm{Ab}$ itself (800 theoretical plates per meter). The focusable property further enhances the detection sensitivity of QD-antibody-DNA.

A BPDE-DNA adduct standard in a genomic DNA size was prepared according to a recent work. ${ }^{17}$ By ultraperformance liquid chromatography tandem mass spectrometry analysis and calibration with stable isotope dilution, it was found that the standard has a total adduct frequency of 5.98 BPDE per $10^{5}$ nucleotides (Supporting Information, Figure S4). By using this wellcharacterized BPDE-DNA adduct standard, we tested the linearity and sensitivity of the method. As shown in Figure 1d, the complexes accounted in the sum of the peak areas of the two complexes increases proportionally to the concentration of the standard (from $2.8 \times 10^{-13}$ to $\sim 2.0 \times 10^{-11} \mathrm{~mol} / \mathrm{L}$ ). The linear dynamic range is over 2 orders of magnitude with a correlation coefficient of $R=0.997(n=5)$. The lower limits of detection are about $1.2 \times 10^{-13} \mathrm{~mol} / \mathrm{L}$ in concentration and $6.6 \times 10^{-21}$

(17) Feng, F.; Wang, X.; Yuan, H.; Wang, H. J. Chromatogr., B 2009, 877, 21042112. mol in mass by estimation from the ratio of signal-to-noise (S/ N) $=3$ after the deduction of background signal. The achieved mass sensitivity is about 5400 times higher than that of nuclease $\mathrm{P} 1$ enhanced ${ }^{32} \mathrm{P}$-postlabeling assays, ${ }^{18,19}$ which is often used in the detection of DNA adducts for human biomonitoring although precaution and restriction for the use of radiation are required.

The achieved ultrasensitivity enables us to determine the BPDE-DNA adducts in cultured human lung carcinoma A549 cells exposed to anti-BPDE, a reactive metabolite of $\mathrm{B}(\mathrm{a}) \mathrm{P}$, as low as $0.1 \mathrm{nM}$. The lowest dose is at least 100 times lower than that of previous works. ${ }^{20-22}$ Human lung cells were hence chosen because of being a major target of $\mathrm{B}(\mathrm{a}) \mathrm{P}$. The BPDE-DNA

(18) Singh, R.; Gaskell, M.; Le Pla, R. C.; Kaur, B.; Azim-Araghi, A.; Roach, J.; Koukouves, G.; Souliotis, V. L.; Kyrtopoulos, S. A.; Farmer, P. B. Chem. Res. Toxicol. 2006, 19, 868-878.

(19) Gyõrffy, E.; Anna, L.; Gyõri, Z;; Segesdi, J.; Minárovits, J.; Soltész, I.; Kostič, S.; Csekeõ, A.; Poirier, M. C.; Schoket, B. Carcinogenesis 2004, 25, 12011209.

(20) Wang, H.; Lu, M.; Mei, N.; Lee, J.; Weinfeld, M.; Le, X. C. Anal. Chim. Acta 2004, 500, 13-20.

(21) Lloyd, D. R.; Hanwalt, P. C. Cancer Res. 2000, 60, 517-521.

(22) Akerman, G. S.; Rosenzweig, B. A.; Domon, O. E.; McGarrity, L. J.; Blankenship, L. R.; Tsai, C. A.; Culp, S. J.; MacGregor, J. T.; Sistare, F. D.; Chen, J. J.; Morris, S. M. Mutat. Res. 2004, 549, 43-64. 

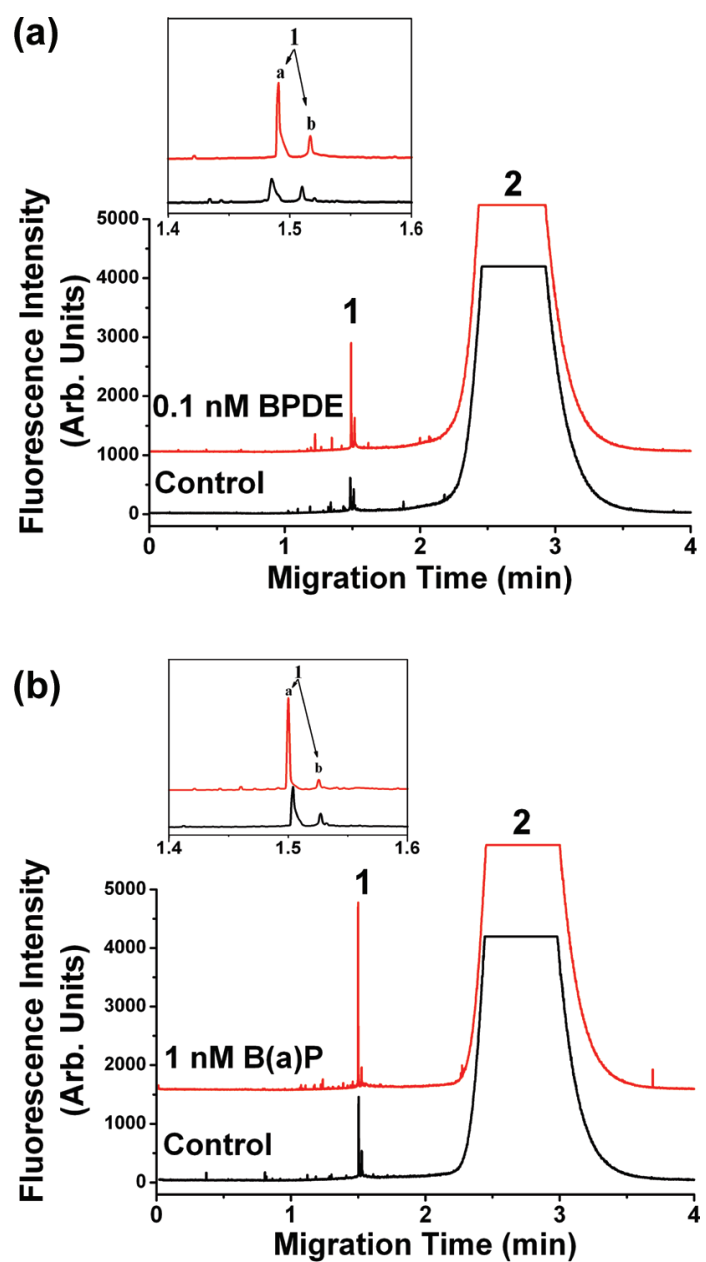

(c)

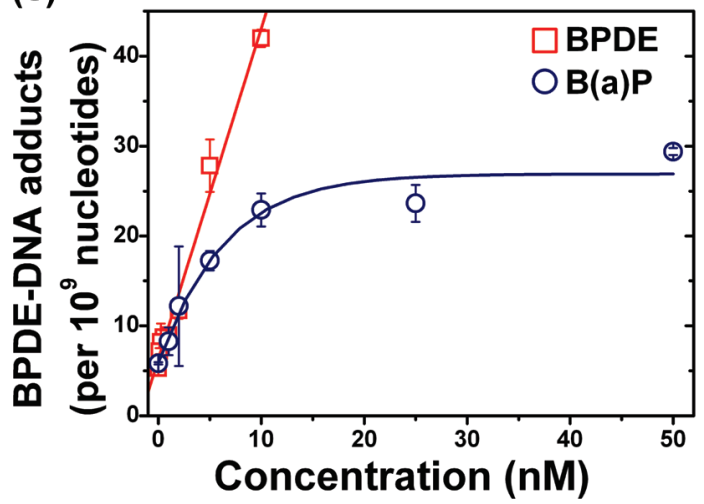

Figure 2. Electropherograms from QD based CE-LIF immunoassay of BPDE-DNA adducts in human lung carcinoma A549 cells by $2 \mathrm{~h}$ exposure to $0.1 \mathrm{nM}$ anti-BPDE (a) or $16 \mathrm{~h}$ exposure to $1 \mathrm{nM} \mathrm{B}(\mathrm{a}) \mathrm{P}$ (b). (c) The dose-response curves for BPDE-DNA adducts in A549 cells treated with $\mathrm{B}(\mathrm{a}) \mathrm{P}(1-50 \mathrm{nM})$ and its reactive metabolite, antiBPDE $(0.1-10 \mathrm{nM})$. Genomic DNA of $5 \mathrm{ng}$ was injected for each analysis.

adducts formed in confluent A549 cells by $2 \mathrm{~h}$ exposure to 0.1 $\mathrm{nM}$ anti-BPDE and $16 \mathrm{~h}$ exposure to $1 \mathrm{nM} \mathrm{B}(\mathrm{a}) \mathrm{P}$ (top traces, Figure $2 \mathrm{a}$ and $2 \mathrm{~b}$ ) can be well distinguished from the control (bottom traces, parts a and b of Figure 2) and corresponding to about $7.8( \pm 0.8)$ and $8.3( \pm 1.5)$ adducts per $10^{9}$ nucleotides by standard calibration $(n=3)$. In contrast, the measured adduct frequency for the control is only about $5.2( \pm 0.5)$ adducts per $10^{9}$ nucleotides. Interestingly, clear dose-response relation-

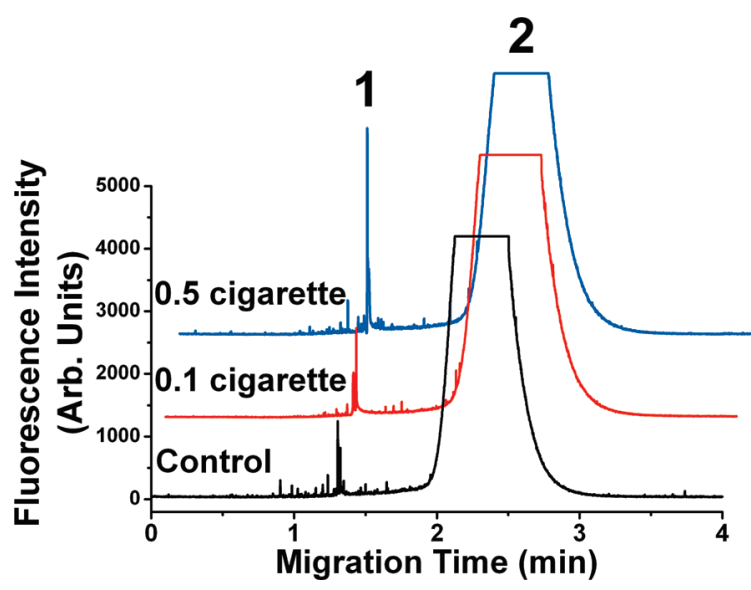

Figure 3. Electropherograms from QD based CE-LIF immunoassays for BPDE-DNA adducts in human A549 cells treated for $16 \mathrm{~h}$ with cigarette smoke condensate from $0,0.1$, and 0.5 cigarettes. Genomic DNA of $5 \mathrm{ng}$ was injected for each analysis.

ships were observed for both exposures even at such never examined low levels. The exposure to anti-BPDE $(0.1-10 \mathrm{nM}$, $2 \mathrm{~h}$ ) exhibits linear dose-response with a correlation coefficient of $R=0.99(n=8)$ (Figure 2c). However, the exposure to bioactivation required $\mathrm{B}(\mathrm{a}) \mathrm{P}(1-50 \mathrm{nM}, 16 \mathrm{~h})$ generates a plateau curve at high doses (Figure 2c), indicating the probable inhibition or saturation of bioactivation of $\mathrm{B}(\mathrm{a}) \mathrm{P}$ at high doses.

Cigarette smoke (CS) that is causally associated with lung cancer and affects about 1.3 billion smokers in the world ${ }^{23}$ contains trace but carcinogenic $\mathrm{B}(\mathrm{a}) \mathrm{P}$. We further determined the trace BPDE-DNA adducts formed in A549 cells treated with CS condensate from less than single cigarette smoke (Figure 3 ). The adduct frequencies in the A549 cells are $4.8( \pm 0.9), 7.9( \pm 0.5)$, and $21.9( \pm 2.9)$ adducts per $10^{9}$ nucleotides for the respective treatment of the CS condensates from $0,0.1$, and 0.5 cigarette, showing a prominent dose-dependent response. The CS condensates induced significantly higher adduct frequency than control $(P<0.007)$. The amount of $\mathrm{B}(\mathrm{a}) \mathrm{P}$ in CS condensate from one cigarette's mainstream smoke is about $20 \mathrm{ng}$ (Supporting Information, Figure S1B and Table S1). With the total nucleotides accounted for in the complete human genome $(3.3 \times$ $10^{9}$ base pairs $)$ and cell number $\left(5.0 \times 10^{6}\right.$ cells per plate), the estimated total BPDE-DNA adducts generated by $1 \mathrm{ng}$ of $\mathrm{B}(\mathrm{a}) \mathrm{P}$ in CS condensate is $5.2 \times 10^{7}$ adducts, which is comparable with that in A549 cells treated by the same amount of $\mathrm{B}(\mathrm{a}) \mathrm{P}$ alone $\left(8.2 \times 10^{7}\right.$ adducts $)$. The results suggest that the measurement of BPDE-DNA adducts by our method is not affected by the presence of other carcinogenic polycyclic aromatic hydrocarbons with similar amounts (Supporting Information, Table S1), showing the high specificity of the method.

In summary, we for the first time report a QD enhanced immunoassay for the detection of trace DNA adducts at environmental exposure levels. The detection mass sensitivity is about 5400 times higher than sensitive ${ }^{32} \mathrm{P}$-postlabeling assays. Moreover, the method consumes only 1000 times less DNA (about $5 \mathrm{ng}$ of genomic DNA) and does not require the labor-intensive and time-consuming DNA digestion and caution-taken radioac-

(23) Hecht, S. S.; Kassie, F.; Hatsukami, D. K. Nat. Rev. Cancer 2009, 9, 476488. 
tive labeling. With benefit from the ultrasensitivity, it enables us to quantify the trace BPDE-DNA adducts in A549 cells exposed to the smoke condensate from 0.1 cigarettes, $1 \mathrm{nM}$ $\mathrm{B}(\mathrm{a}) \mathrm{P}$, and $0.1 \mathrm{nM}$ anti-BPDE. The ultrasensitive assay of BPDE-DNA adducts can be applied to DNA repair studies, human exposure biomonitoring, assessment of cancer risk and population susceptibility, and chemoprevention study. This method also shows promising applications of bright QD to various DNA analyses, including damage analysis. The achieved ultrasensitivity benefits from the exceptional optical properties and well-controlled nanosuface of QD and from the highly efficientseparation and focusing of QDs by capillary electrophoresis.

\section{ACKNOWLEDGMENT}

This work was supported by the grants from the National Basic Research Program of China (Grants 2007CB407305, 2008CB417201, and 09CB421605), the National Natural Science Foundation of China (Grant 20877091, 20890112, 20677066, and 20621703), and the Chinese Academy of Sciences (Grant YZ200749) to Dr. H. Wang. We thank Dr. Moon-shong Tang (New York University) for valuable discussion and suggestions.

\section{SUPPORTING INFORMATION AVAILABLE}

Additional information as noted in text. This material is available free of charge via the Internet at http://pubs.acs.org.

Received for review September 21, 2009. Accepted November 2, 2009.

AC9021105 